\title{
SARS: a szuperszonikus betegségek korának kezdete - in memoriam Carlo Urbani (1956-2003)
}

\author{
Felkai Péter dr. \\ Debreceni Egyetem, Orvostudományi Kar, Belgyógyászati Intézet, Anyagcsere-betegségek Tanszék, \\ Utazásorvostani Tanszéki Csoport, Debrecen
}

Az utazás kockázati tényezői között előkelő helyet foglalnak el a helyi endémiás fertőző betegségek okozta egészségi problémák. Ezen megbetegedések nemcsak a fertőzött területre utazókat fenyegetik, de az onnan elutazókat is, akik akvirálva a kórt, a világ különböző pontjaira hurcolhatják ezeket a megbetegedéseket. Köszönhetően a nagy hatósugarú sugárhajtómúves repülőgépek használatának az interkontinentális utazások során (melyek ráadásul ötszáznál is több utast képesek szállítani egyszerre), a világ bármely részét 24 óra alatt elérheti az utazó, de a betegséget hordozó vektor is. Az utazók által okozott első pandémia 16 éve, 2002-ben tört ki és ébresztette rá a világot az utazók által hordozott betegségek veszélyére. A kór felfedezője, Carlo Urbani, aki önfeláldozásával valószínúleg megmentette a világot egy félelmetes pandémiától, 15 éve halt meg. De vajon tanultunk-e a történtekből?

Azt a tényt, hogy az utazók, kereskedők és áruik, a hadseregek a fertőzések elsődleges vektoraként szerepelnek, a középkori nagy pestisjárvány (1347-1351) közben ismerték fel a közegészségügyért felelős hivatalnokok és orvosok. Védekezésképpen 1348-ban elsőként Velencében vezették be a városba érkező idegenek izolálását egy külön szigeten (1. ábra) - így megszületett a

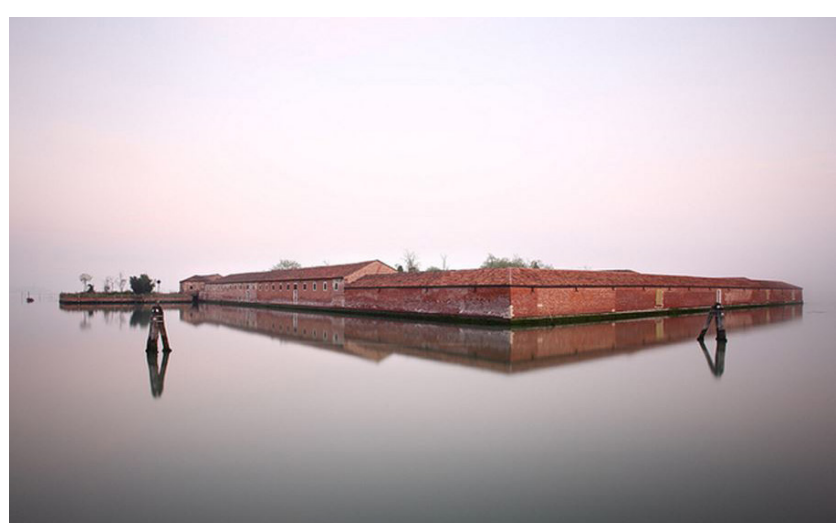

1. ábra

Lazzaretto Vecchio, a világ első karanténszigete. Balra fent az első szigeten tanyázott a karantén fegyveres őrsége, és a falakka körbevett területet nem lehetett észrevétlenül megközelíteni karantén intézménye [1], melynek neve - mint közismert - az elkülönítés időtartamának olasz szavaiból (40 nap - quaranta giorni) ered.

Az intézkedés hatásos volt - feltéve, hogy szigorúan betartották. Az első, számos halálos áldozattal járó újkori influenzapandémia, a „spanyolnátha” a Föld lakosságának majdnem a felét megbetegítette. Már kitörésének első évében, 1918-ban több áldozatot követelt, mint az egész első világháború, fennállásának 3 éve alatt pedig halálos áldozatainak száma túlnőtt az emberiséget addig sújtó legnagyobb járványok produkálta veszteségeken [2]. Az elképesztően nagy virulenciájú vírus $\left(\mathrm{H}_{1} \mathrm{~N}_{1}\right)-$ mely előjelzője volt a gyors antigénváltozást produkáló influenzavírusok fenyegetésének - egy amerikai egyesült államokbeli katonai táborban, Fort Riley-ben bukkant fel, és a csapatok mozgásával Franciaországba jutott [3]. Innen gyorsan elterjedt kontinensszerte. A vírus valószínúleg az angol haditengerészek közvetítésével indult el világ körüli útjára, mivel az angol flotta szállította az expedíciós erőket Európába.

Mivel Spanyolország a háborúban semleges ország volt, az ottani cenzúra viszonylag enyhe volta miatt a franciaországi járvány híre először a spanyol sajtóban jelent meg. A hadviselő országokkal ellentétben itt nem tartották titokban a járványt. Ezért - igaztalanul - a járványon rajta maradt a „spanyolnátha” kifejezés. Sok halálesetet a háborús nélkülözéseknek és a katonák legyengült szervezetének is tulajdonítottak. Ludendorff tábornok, a császári haderô főszállásmestere a német vereség küszöbén még reménykedett, hogy a francia csapatokat betegség tizedelte állapotban még legyőzheti [4], de mikor a betegség a német katonákat is elérte, a kudarcokat a hadsereg influenza okozta rossz harckészségének és rossz állapotának tulajdonította. A spanyolnáthavírusterjedés megfékezése érdekében a vezető amerikai katonaorvosok csak a legszükségesebb hajóutakat engedélyezték, és gyakorlatot tartottak a fertőző betegek kimentésének fogásaiból. Kikötés előtt minden hajónak a kikötőben kellett volna vesztegelnie, amíg ki nem derült, hogy van-e beteg vagy vírushordozó a fedélzeten. Eze- 
ket az intézkedéseket azonban nem tartották be, így a vírus akadálytalanul folytatta gyilkos terjedését.

A járvány hirtelen megszűnt, és újult erővel tört ki 1919-ben: nem tudni, hogy a rekurrens vírusterjedésben a háború végén a frontról győzedelmesen hazatérő katonák ölelgetése mekkora szerepet játszott. De a kór így is már hónapos lépésekben terjedt az egyes geográfiai régiók között.

Egészen az 1960-as évekig kellett várni arra, hogy a Földet bárki 24 óra alatt megkerülhesse - ez a teljesítmény a sugárhajtású utasszállítók menetrendbe állításának volt köszönhető. Az utazók ilyen gyors transzportjával természetesen a járványok terjedési sebessége is elérte a Föld forgásának idejét: a földgolyó bármely pontjáról bármely virulens fertőzés egy nap alatt hozzánk érkezik, mindez olyan sebességgel, ahogy a repülőgép halad. Az első figyelmeztetést a maláriaszúnyog adta. Az 1960-as évek végén figyeltek fel arra, hogy olyan egyének is maláriafertőzésben betegedtek meg, akik a közelében sem jártak a maláriafertőzött területeknek [5]. Hamarosan kiderült, hogy az eseteket olyan Anopheles-szúnyogok idézték elő, melyek az epidemikus területen kerültek a repülőgépek kabinjába, és onnan szabadultak ki, többek között olyan európai nagyvárosokban, mint Párizs, Zürich vagy London $[6,7]$. Az ilyen kóreredetű maláriafertőzést elnevezték repülőtéri- vagy kifutópálya-maláriának, és védekezésképpen a WHO (World Health Organization - Egészségügyi Világszervezet) elrendelte a fertőzött területről induló repülőgépek kabinjának piretroidtartalmú aeroszollal való bepermetezését az utasok beszállása és a kabin légmentes lezárása után [8]. Egy ideig ez megfelelő megoldásnak tûnt, és a permetezés az utasok egészségét sem veszélyeztette, de Nyugat-Afrikában a piretroidrezisztens Anopheles gambiae-fajok kicselezték a WHO és az IATA (International Air Transport Association - Nemzetközi Légi Szállítási Szövetség) rendelkezéseit.

A következő figyelmeztetés már durvábbra sikerült. Egy, a maga nemében az első olyan modern pandémia 2003 februárjában sokkolta a világot, mely a sugárhajtású repülőgépek sebességével hordozta a vektorokat a messzi tájakra.

Egy amerikai üzletember, Johnny Chen Hongkongból utazott Hanoiba, ahol leszállították a repülőgépről fulladásos tünetek miatt, és - mint igényes külföldit nem az egyik hanoi közkórházba, hanem az elegáns Francia Kórházba szállították. A tüdőgyulladás-szerű tüneteket mutató páciens hamar átragasztotta betegségét az őt ápoló kórházi személyzetre. A kezelőorvosok - akik egy különösen rossz prognózisú influenzának tartották az esetet - konzíliumot kértek az olasz dr. Carlo Urbanitól, aki gyorsan felismerte, hogy valami nagyon virulens vírus okozta rapid terjedésú új, nem influenzás megbetegedésről van szó: el is nevezte azt „súlyos akut légzési szindrómának" (severe acute respiratory syndrome) azaz rövidítve SARS-nak. Mr. Chen hamarosan meghalt légzési elégtelenségben.

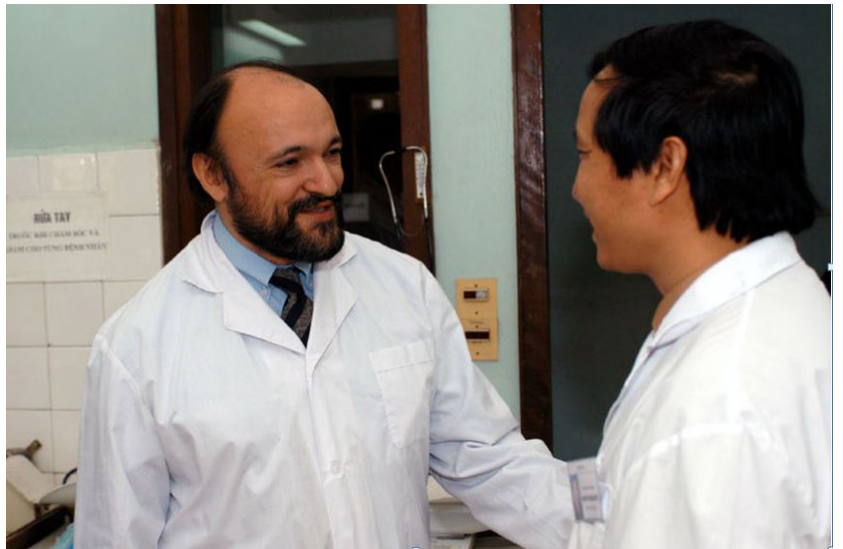

2. ábra

Urbani doktor vietnami kollégájával. Még csak egy hónapja fe dezte fel a SARS-betegséget, mikor ő maga is belehalt. 46 éves volt csupán

Dr. Urbani (2. ábra) mint neves infektológus dolgozott hazájában, ahol az Orvosok Határok Nélkül nevú nemzetközi segélyszervezet olaszországi elnökévé is választották. A WHO munkatársaként Hanoiban dolgozott mint a fertőző betegségek felszámolásának szakértője. 2003 márciusában éppen az új betegségről tartott volna előadást Thaiföldön, amikor a repülőút alatt már lázasnak érezte magát, úgyhogy a repülőtéren mentőt kellett hozzá hívni. A mentőgépkocsi csak 90 perc múlva érkezett meg, mert a személyzetnek hirtelenében nem találtak megfelelő védőöltözéket. Egy bangkoki kórház elkülönítőjébe került, ahol légzési elégtelenség miatt lélegeztetőgépre tették. Utolsó pillanataiban, miután feladták neki az utolsó kenetet, tüdőszövetét még felajánlotta a SARS vírusának kitenyésztéséhez.

Időközben kiderült, hogy a SARS már négy hónappal a hanoi eset elött megjelent Kína Hongkonggal szomszédos tartományában, 806 megbetegedést és 35 halálesetet okozván, de a kínai hatóságok ezt nem jelentették a WHO-nak, és később is megtagadták a WHO küldötteinek helyszíni vizsgálódását [9]. A témával foglalkozó tudósok rekonstruálták a pandémia kirobbanásának menetrendjét: lényegében ez volt az első olyan, járvánnyal összefüggő nemzetközi biometriai térkép (ha nem számítjuk John Snow doktor koleratérképét 1854-ből), amely pontosan ábrázolta a SARS útját és a fertőzöttek számát (3. ábra).

Hongkongba a betegséget egy kínai orvos, dr. Liu Jian-lun hurcolta be 2003 februárjában, aki egy Guangdong tartománybéli földmúvest kezelt 2002 végén a súlyos, halállal végződött felső légúti betegséggel. A földmúves egy évvel a hongkongi behurcolás előtt halt meg, diagnózisa ismeretlen maradt. Noha történt néhány izolációs kísérlet a helyi járvány lokalizálására, a kínai hatóságok nem értesítették megfelelő módon a WHO-t. A diktatúrákban megszokott titkolózásból, vagy mert nem tartották a járványt jelentősnek - nem tudni. 


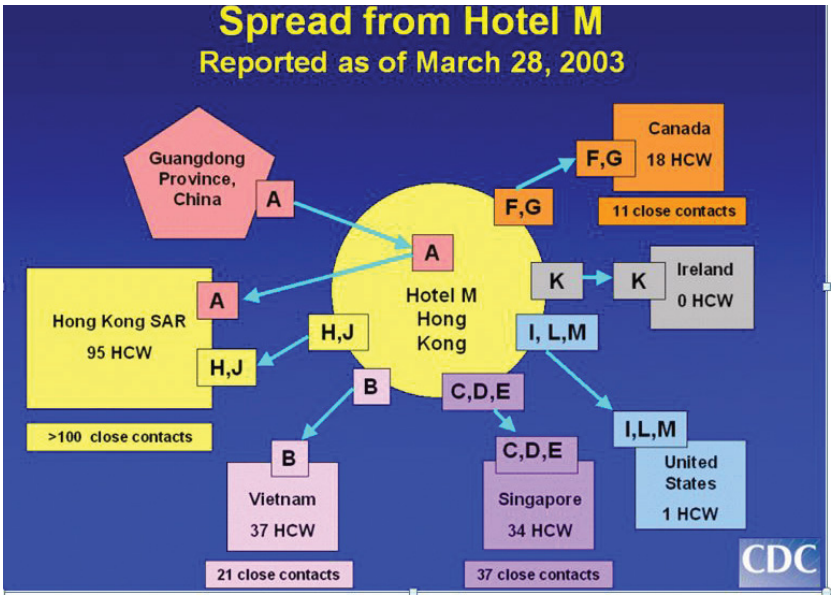

3. ábra

A SARS-fertózés kontagiozitása. A vírusgazdák nagybetúkkel vannak jelölve, a HCW a beteg által megfertőzött egészségügyi személyzet számát mutatja (dr. Julie Gerberding, a CDC igazgatójának ábrája)

A kínai orvos a Hotel Metropole 9. emeleti szobájában szállt meg. 16 hotelvendéget betegített meg, közöttük a már említett amerikai üzletembert. A vendégek (és ápolóik) szétszéledtek a világban, magukkal hurcolva a halálos vírust. A Hongkongban kórházba került, túlélő betegek egy csoportját 2003. március végén engedték el. Ezek a gyógyultnak nyilvánított betegek voltak a vírushordozók, akik elvitték a kontinensekre a vírusokat ( 1 . táblázat).

Egy másik fertőzőgóc Amoy Gardensben, egy hongkongi lakóparkban alakult ki, mely fertőzést valószínúleg a csatornarendszer eldugulása okozta. A helyi civil szerveződések, tartván attól, hogy a kormányzat nem kellő időben és nem megfelelően tájékoztatja a lakosságot a SARS-járvány veszélyéról, létrehozták a „sosick.org” internetes honlapot, melyen azután, sajnos, nem csak valid információk keringtek.

Mi okozhatta a járvány ilyen mérvű és sebességű terjedését? Elsősorban a vírus magas kontagiozitása [10]. Másodsorban az utazás sebességének (sugárhajtású repülőgép) hihetetlen mértékű felgyorsulása. Ehhez persze szükséges a repülőgépkabinok sajátos belső, az utasok

1. táblázat | A világ különböző országaiba behurcolt SARS miatti halálesetek száma

\begin{tabular}{llc}
\hline Kontinens & Ország & A halálesetek száma \\
\hline Észak-Amerika & Kanada & 44 \\
& Amerikai Egyesült Államok & 4 \\
\hline Ázsia & Hongkong & 299 \\
& Taiwan & 37 \\
& Kína & 349 \\
& Szingapúr & 33 \\
& Fülöp-szigetek & 2 \\
& Vietnam & 5 \\
\hline
\end{tabular}
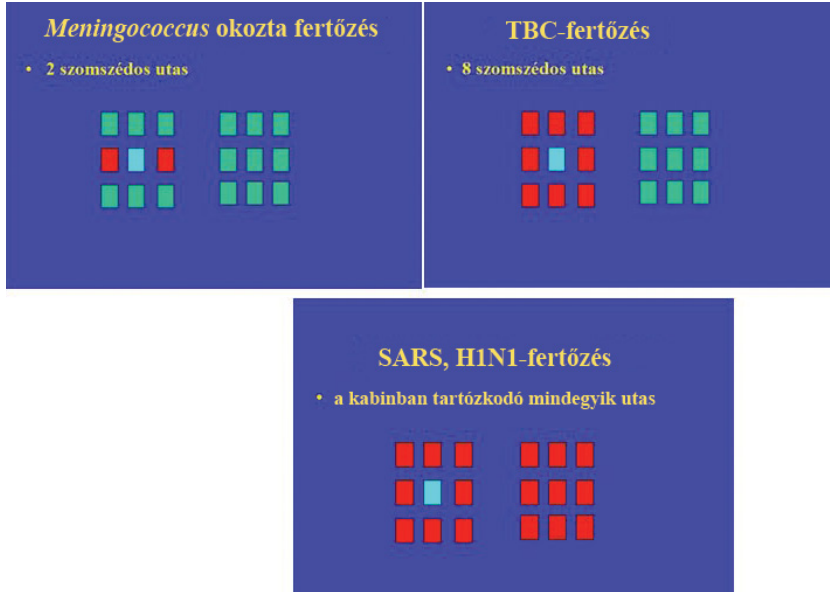

4. ábra

A repülőgépek kabinjában tartózkodó szomszédos utasok meg betegedése különböző fertőző betegségek esetén

számára kedvezőtlen környezete, szellőztetési rendszere és az utastér zsúfoltsága. Mindez odavezet, hogy az egyes, cseppfertőzéssel terjedő járványos megbetegedések nagymértékben fertőzik meg az utastársakat: ebből a szempontból sajnos a vírusok kontagiozitása a legveszélyesebb (4. ábra) [11]. A repülógéppel utazók vírushordozását jól mutatja a WHO utánkövetése a SARS-járvány alatt: a CAl12-es járat, melyen a kínai orvos is utazott, a Hongkongba érkező, SARS-ban megbetegedett 27 utazó közül 22-nek a haláláért volt felelős (5. ábra) [12].

A WHO jelentése szerint 8273 személy betegedett meg a SARS-járványban, ezek közül $775(9,6 \%)$ halt meg. Hetek alatt terjedt el a járvány Ázsiából a világ 29 különböző távoli országába [13]. A járvány kitörése elején, amíg a beteggel érintkezők nem folyamodtak védőöltözékhez, az összes megbetegedettnek mintegy háromnegyed része az egészségügyi személyzet munkatársai közül került ki! [14]. Dr. Urbani riasztása nyomán aktivizálódott a WHO apparátusa, hogy megszervezze az

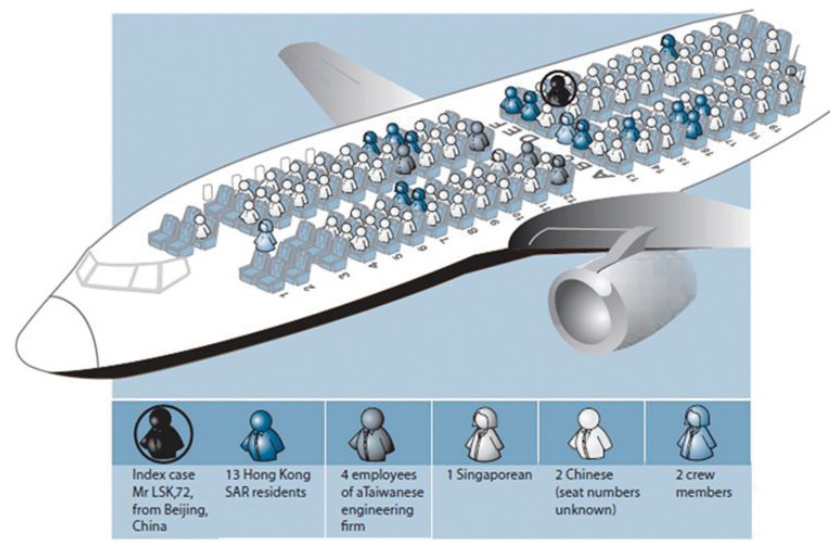

5. ábra

A kínai orvos helye a CAl12-es járaton, amellyel Hongkongba utazott. 22 utastársát fertőzte meg (Olsen és mtsai [12] nyomán) 
újkori történelem legnagyobb pandémiájával fenyegetó veszély megelőzését. Ugyancsak az ő gyors helyzetfelismerésének volt köszönhető, hogy a Vietnami Egészségügyi Minisztérium elrendelte a gyanús betegek elkülönítését és az utazók szûrését, így lassítva a rohamosan terjedő járvány sebességét. A SARS hatására a WHO, a CDC (Centers for Disease Control and Prevention - Betegségmegelőzési és Járványvédelmi Központ; az amerikai járványügyi hivatal) és az Európai Unió is felállította a maga korai járványfigyelő rendszerét (ECDC; European Centre for Disease Prevention and Control - Európai Betegségmegelőzési és Járványvédelmi Központ), és kidolgozták a megelőzés és az azonnali intézkedés forgatókönyvét [15]. Ezen intézkedések alapjainak lerakása jelenleg is folyik az unió keretein belül, így hazánkban is [16], ahol szintén felbukkantak SARS-gyanús esetek [17]. Ennek köszönhetően a madár-, illetve a sertésinfluenza-járvány fenyegetésekor már felkészültebben állhattak a kormányzat felelósei a vírus terjedésének útjába.

A világon eddig végigsöpört járványok, így a SARS is szerepet játszott a WHO legújabb, 2007. évi Nemzetközi Egészségügyi Rendszabályzatának kialakításában. Ez a dokumentum deklarálja a tagállamok közös álláspontját, miszerint a betegségek nemzetközi terjedésének megakadályozására a megelőzés és a védekezés a megfelelő közegészségügyi válasz. Ennek a válasznak azonban a közegészségügyi kockázattal arányos mértékúnek kell lennie, hogy ne zavarja feleslegesen a nemzetközi utasforgalmat [16].

Mindenesetre az utazásokkal terjedő járványok lefolyásának elemzése tanulságos lehet a mai kor törvényhozói és hatóságai számára is: „növeli, ki elfödi a bajt” - az időben megtett, az állampolgárokkal való őszinte kommunikáció és az intézkedések következetes betartása a járványok okozta biológiai kár csökkentésének evidens, becsületes és legolcsóbb módja. A bizonytalan vagy bármely állami vagy üzleti érdekből eltitkolt információk sok ember halálát okozzák. A XXI. században a középkori módszerek (például karantén) is hasznosnak bizonyultak volna, ha határozottan használják azokat. Az, hogy nem történt sokkal nagyobb tragédia a világ elsô „szuperszonikus” fertőző betegségével való találkozáskor, pusztán az emberiség szerencséjén és egy talpraesett, szakmájához kiválóan értő orvoson múlott. Ezekkel a tanulságokkal szolgált számunkra a SARS-járvány, mely kevesebb mint fél év alatt megváltoztatta a járványügyi és utazásorvostani szakemberek gondolkodását. Remélhetőleg a politikusokét is.

\section{Irodalom}

[1] Gensini, GF, Yacoub MH, Conti AA. The concept of quarantine in history: from plague to SARS. J Infect. 2004; 49: 257-261.

[2] Johnson NP, Mueller J. Updating the accounts: global mortality of the 1918-1920 "Spanish" influenza pandemic. Bull Hist Med. 2002; 76: 105-115.

[3] Burnet FM, Clark E. Influenza: a survey considered that the introduction of influenza into England was by way of troops returning from France, but suggested it may have occurred in June 1918. The Times, 15 January 1920; p. 9.

[4] McCallum J. Influenza pandemic, 1918-1920. In: Tucker SC. (ed.) The encyclopedia of world war I. ABC-Clio Inc., Santa Barbara, CA, 2005; p. 576.

[5] Isaäcson M. Airport malaria: a review. Bull World Health Organ. 1989; 67: 737-743.

[6] Evans BR, Joyce CR, Porter JE. Mosquitoes and other arthropods found in baggage compartments of international aircraft. Mosquito News 1963; 23: 9-12.

[7] Guillet P, Germain MC, Giacomini T, et al. Origin and prevention of airport malaria in France. Trop Med Int Health 1998; 3 : $700-705$.

[8] Report of the Informal Consultation on Aircraft Disinsection. WHO/HQ, Geneva, 6-10 November 1995.

[9] Rosenthal E, Altman LK. China raises tally of cases and deaths in mystery illness. The New York Times, March 27, 2003.

[10] Hui DS, Chan PK. Severe acute respiratory syndrome and coronavirus. Infect Dis Clin North Am. 2010; 24: 619-638.

[11] Gupta JK, Lin CH, Chen Q. Risk assessment of airborne infectious diseases in aircraft cabins. Indoor Air 2012; 22: 388-395.

[12] Olsen SJ, Chang HL, Cheung TY, et al. Transmission of severe acute respiratory syndrome on aircraft. N Engl J Med. 2003; 349: 2416-2422.

[13] WHO: Update 62 - More than 8000 cases reported globally, situation in Taiwan, data on in-flight transmission, report on Henan Province, China, 22 May 2003. http://www.who.int/ csr/don/2003_05_22/en/ [accessed: September 18, 2018].

[14] Omi S. (ed.) WHO: SARS: how a global epidemic was stopped. Western Pacific Region, Geneva, 2006.

[15] Smith RD. Responding to global infectious disease outbreaks. Lessons from SARS on the role of risk perception, communication and management. Soc Sci Med. 2006; 63: 3113-3123.

[16] Act XCI of 2009 on the Announcement of Health Care Regulations of WHO. [2009. évi XCI. törvény az Egészségügyi Világszervezet Nemzetközi Egészségügyi Rendszabályainak kihirdetéséről. 2. \$ 2. cikk.] [Hungarian]

[17] Rókusz L, Jankovics I, Jankovics M, et al. Importance of the case of coronavirus-associated severe acute respiratory syndrome detected in Hungary in 2005. [Miért aktuális 2013-ban a súlyos akut respirációs szindrómát okozó coronavírus-fertőzés 2005ben Magyarországon igazolt esete?] Orv Hetil. 2013; 154: 1877-1882. [Hungarian]

(Felkai Péter dr., Budapest, Szentendrei út 301., 1039 e-mail: peter.felkai@soshungary.hu) 